\title{
Efektivitas Mouthwash Berbahan Dasar Ekstrak Camellia sinensis dan Mentha piperita sebagai Antibakteri terhadap Streptococcus mutans
}

\author{
Dennia Oktavia Zahidah Hulwah' ${ }^{1}$, Jihan Bobsaid ${ }^{2}$, Muflikhah Ramadhani ${ }^{1}$, Yuani Setiawati ${ }^{3}$ \\ ${ }^{1}$ Program Studi Kedokteran, Fakultas Kedokteran, Universitas Airlangga, Surabaya, Indonesia \\ ${ }^{2}$ Program Studi Pendidikan Apoteker, Fakultas Farmasi, Universitas Airlangga, Surabaya, \\ Indonesia \\ ${ }^{3}$ Departemen Farmakologi, Fakultas Kedokteran, Universitas Airlangga, Surabaya, Indonesia \\ Alamat Korespondensi: dennia.oktavia.zahidah-2018@fk.unair.ac.id
}

\begin{abstract}
Abstrak
Karies gigi merupakan masalah kesehatan yang disebabkan Streptococcus mutans. Salah satu upaya mencegah karies gigi adalah melalui penggunaan mouthwash. Oleh karena mouthwash di pasaran tinggi alkohol sehingga meningkatkan risiko kanker mulut, maka diperlukan formulasi mouthwash berbahan dasar tanaman herbal. Tanaman herbal yang memiliki aktivitas antibakteri diantaranya teh hijau (Camellia sinensis) dan peppermint (Mentha piperita). Penelitian ini bertujuan untuk mengetahui efektivitas mouthwash ekstrak teh hijau dan peppermint sebagai antibakteri terhadap Streptococcus mutans. Aktivitas antibakteri ditentukan melalui pengukuran zona hambat pada uji difusi. Mouthwash dibuat dalam 5 formula yaitu F1, F2, F3, F4, F5 dengan konsentrasi 20\%, 40\%, 60\%, 80\%, dan 100\%. Dibuat pula FA (mouthwash ekstrak teh hijau 20\%) dan FB (mouthwash ekstrak peppermint 20\%) sebagai pembanding. Hasil penelitian menunjukkan bahwa semakin tinggi konsentrasi ekstrak teh hijau dan peppermint maka semakin besar diameter zona hambat. Rata rata zona hambat F1 dan F2 8,34 dan 9,80 mm (daya hambat sedang). Rata rata zona hambat F3, F4 dan F5 masing masing 11,64 mm, 14,63 mm dan 15,91 mm (daya hambat kuat). Rata rata zona hambat FA dan FB 7,45 dan $6,20 \mathrm{~mm}$ (daya hambat sedang). Berdasarkan hasil tersebut disimpulkan bahwa mouthwash ekstrak Camellia sinensis dan Mentha piperita efektif sebagai antibakteri terhadap Streptococcus mutans.
\end{abstract}

Kata Kunci: antibakteri, Camellia sinensis, Mentha piperita, mouthwash, Streptococcus mutans

\section{Effectivity of Camellia sinensis and Mentha piperita Extract-based Mouthwash as Antibacteria against Streptococcus mutans}

\begin{abstract}
Dental caries is caused by Streptococcus mutans. The use of mouthwash can prevent caries. Over-the-counter mouthwash contains alcohol that increases the risk of oral cancer. Herbal mouthwash is required. Herbal plants with antibacterial activity include green tea (Camellia sinensis) and peppermint (Mentha piperita). This study aims to determine the effectiveness of mouthwash made from green tea and peppermint as antibacterial against Streptococcus mutans. Antibacterial activity determined by measuring inhibition zone. Mouthwash is made in 5 formulas, F1, F2, F3, F4, F5 with a concentration of $20 \%, 40 \%, 60 \%, 80 \%$, and $100 \%$. The formulas of FA (mouthwash with $20 \%$ green tea extract) and FB (mouthwash with $20 \%$ peppermint extract) were also made for comparison. Results showed that the higher the concentration of green tea and peppermint extract, the larger the diameter of inhibition zone. The inhibition zone of F1 and F2 were 8.34 and $9.80 \mathrm{~mm}$ (medium inhibitor). The inhibition zone of F3, F4, and F5 were $11.64 \mathrm{~mm}, 14.63 \mathrm{~mm}$, and $15.91 \mathrm{~mm}$ (strong inhibitor). The inhibition zone of $F A$ and $F B$ were 7.45 and $6.20 \mathrm{~mm}$ (medium inhibitor). It is concluded that mouthwash made from Camellia sinensis and Mentha piperita extract is effective as antibacterial against Streptococcus mutans.
\end{abstract}

Keywords: antibacteria, Camellia sinensis, Mentha piperita, mouthwash, Streptococcus mutans

How to Cite :

Hulwah D. O. Z., Bobsaid J., Ramadhani M., Setiawati Y. Efektivitas Mouthwash Berbahan Dasar Ekstrak Camellia sinensis dan Mentha piperita sebagai Antibakteri terhadap Streptococcus mutans. J Kdokt Meditek. 28(1), 30-39. Available from:

http://ejournal.ukrida.ac.id/ojs/index.php/Meditek/article/view/2314/version/2304 DOI: https://doi.org/10.36452/jkdoktmeditek.v28i1.2314 


\section{Pendahuluan}

Masalah kesehatan gigi dan mulut merupakan salah satu masalah kesehatan yang banyak terjadi di masyarakat dan memerlukan penanganan yang serius. Hampir setengah dari populasi penduduk dunia mengalami masalah kesehatan gigi dan mulut khususnya karies gigi. ${ }^{1}$ Di Indonesia, karies gigi menempati proporsi terbesar dalam masalah gigi nasional yakni sebesar $45,3 \% .^{2}$ Prevalensi karies gigi di Indonesia menunjukkan pola peningkatan yang cukup signifikan dari tahun ke tahun. Berdasarkan hasil riset kesehatan dasar, prevalensi karies gigi pada tahun 2007 sebesar $43,4 \%$ meningkat menjadi $53,2 \%$ pada 2013 , dan semakin meningkat pada tahun 2018 menjadi sebesar $88,8 \% .^{2}$

Karies gigi merupakan penyakit akibat aktivitas bakteri yang menyerang jaringan keras gigi sehingga menimbulkan demineralisasi gigi. ${ }^{3}$ Strain bakteri utama yang menyebabkan karies gigi adalah Streptococcus mutans. ${ }^{4}$ Streptococcus mutans merupakan bakteri kariogenik oral yang dapat bertahan dalam suasana asam. Bakteri ini memiliki kemampuan untuk memfermentasi karbohidrat. Glukosa dan sukrosa yang terkandung dalam sisa makanan dimetabolisme dan diubah oleh Streptococcus mutans menjadi Extracellular Polysaccharide Matrix (EPS) sehingga terbentuk plak gigi yang memudahkan bakteri untuk melekat. ${ }^{4}$ Setelah membentuk kolonisasi permanen pada permukaan gigi melalui pembentukan plak, Streptococcus mutans menghasilkan asam organik melalui proses fermentasi karbohidrat dimana asam tersebut akan berdifusi ke dalam enamel, dentum atau sementum dan menghancurkan kristal mineral hingga terbentuk lubang atau kavitas pada gigi. ${ }^{5}$ Karies gigi berkepanjangan berdampak pada penurunan kualitas hidup seperti menurunnya nafsu makan yang menyebabkan malnutrisi dan gangguan pertumbuhan, gangguan tidur, gangguan perkembangan kognitif pada anak serta menyebabkan inflamasi kronis. ${ }^{6}$

Salah satu upaya mencegah karies gigi adalah melalui penggunaan mouthwash. Mouthwash merupakan larutan dengan kandungan antimikroba yang digunakan untuk memberikan kesegaran pada rongga mulut dan membersihkan plak serta mikroorganisme patogen penyebab penyakit rongga mulut. ${ }^{7,8}$ Mouthwash yang beredar di pasaran pada umumnya mengandung alkohol yang cukup tinggi padahal penggunaan mouthwash dengan kandungan alkohol 25\% atau lebih meningkatkan risiko kanker mulut sebesar $50 \% .^{9}$
Alternatif yang dapat dipilih untuk mengatasi masalah tersebut adalah dengan menggunakan mouthwash berbahan dasar ekstrak tumbuhan herbal yang memiliki aktivitas antibakteri seperti teh hijau (Camellia sinensis) dan peppermint (Mentha piperita).

Teh hijau (Camellia sinensis) memiliki kandungan katekin yang sangat tinggi. Katekin merupakan senyawa polifenol dari golongan flavonoid yang berperan sebagai antimikroba karena dapat merusak dinding sel mikroorganisme. ${ }^{10}$ Ekstrak daun teh hijau dapat menghambat bakteri Streptococcus mutans yang dibuktikan dengan hasil uji aktivitas antibakteri dan uji One-way ANOVA yang menunjukkan bahwa ekstrak polifenol Camellia sinensis 100\% kontrol positif memiliki daya hambat tertinggi terhadap pertumbuhan Streptococcus mutans dibandingkan konsentrasi 10\%, 20\%, 30\%, 40\%, dan 50\%. ${ }^{11}$ Kandungan senyawa lain pada daun teh hijau yang turut berperan sebagai antimikroba adalah alkaloid, saponin, tanin, fenol, steroid dan glikosida. $^{12}$

Pada daun peppermint (Mentha piperita) terdapat kandungan minyak atsiri yang mengandung mentol dan menthone yang memiliki aktivitas antimikroba. ${ }^{13}$ Minyak atsiri dalam peppermint dapat berperan sebagai antibakteri terhadap Streptococcus mutans dengan nilai Minimum Inhibitory Concentration (MIC) dan MBC Minimum Bactericidal Concentration (MBC) masing masing sebesar $10,5 \mu \mathrm{g} / \mathrm{mL}$ dan $16,3 \mu \mathrm{g} / \mathrm{mL} .{ }^{14}$ Selain itu, daun peppermint juga mengandung senyawa fenolik, tanin, flavonoid, menthofuran, dan triterpenoid yang memiliki kemampuan membunuh bakteri. ${ }^{15,16}$

Berdasarkan uraian tersebut, maka dilakukan penelitian untuk menguji efektivitas mouthwash berbahan dasar kombinasi ekstrak Camellia sinensis (teh hijau) dan Mentha piperita (peppermint) sebagai antibakteri terhadap Streptococcus mutans. Pemilihan teh hijau didasarkan pada penelitian yang menemukan bahwa teh hijau merupakan salah satu tanaman dengan kandungan flavonoid tertinggi dan termasuk dalam komoditas perkebunan utama di Indonesia. ${ }^{17,18}$ Sementara itu peppermint dipilih karena memiliki kandungan menthol paling tinggi diantara spesies tanaman mint serta adanya kecenderungan masyarakat yang lebih menyukai produk herbal dengan aroma dan rasa peppermint. ${ }^{15,19}$ Penerapan kombinasi kedua tanaman ini didasarkan pada penelitian sebelumnya yang menunjukkan bahwa multi-plant extracts (ekstrak yang dibuat dari campuran 
beberapa tanaman) memiliki aktivitas antibakteri yang lebih superior dibanding single plant extract. ${ }^{20}$

\section{Metodologi}

Penelitian ini merupakan penelitian eksperimental, dan dilaksanakan bulan JuniSeptember 2021 di Laboratorium Materia Medica Batu, Laboratorium Poltekkes Malang dan Research Center Fakultas Kedokteran Gigi Universitas Airlangga dengan memperhatikan protokol kesehatan (Prokes).

Pengambilan data efektivitas mouthwash dilakukan secara langsung di dalam laboratorium dengan melihat dan mencatat objek perlakuan yakni uji daya hambat bakteri Streptococcus mutans.

Alat yang digunakan dalam penelitian ini adalah gelas beaker, gelas ukur, tabung reaksi, spatula, rotavapor, soklet, oven, shaker, waterbath, timbangan digital, pipet tetes, blender, botol kaca, mikropipet, cawan petri, spreader, pembakar bunsen, ose, dan indikator universal.

Bahan yang digunakan dalam penelitian ini adalah daun teh hijau (Camellia sinensis), daun peppermint (Mentha piperita), aquades, etanol, $\mathrm{NaCl}$, asam benzoat, sorbitol, peppermint oil, larutan $\mathrm{HCl}$, reagen Dragendorff, reagen Mayer, reagen Wagner, air panas, $\mathrm{FeCl}_{3} 3 \%$, serbuk $\mathrm{Mg}$, asam asetat anhidrat, $\mathrm{H}_{2} \mathrm{SO}_{4}$ pekat, benzena, amonia, dan TYC agar base. Bahan utama mouthwash pada penelitian ini adalah daun teh hijau (Camellia sinensis) yang dipetik dari kebun teh Wonosari, kecamatan Lawang, kabupaten Malang dan daun peppermint (Mentha piperita) yang dipetik dari perkebunan di kecamatan Blimbing, kabupaten Malang.

Determinasi tanaman dilaksanakan di laboratorium Materia Medica Batu dan didasarkan pada beberapa literatur rujukan meliputi Serial data ilmiah terkini tumbuhan obat, Flora of Java Volume I, Flora of Java Volume II, dan FLORA. ${ }^{21-}$ ${ }^{24}$ Hasil determinasi menyatakan bahwa spesimen tanaman yang digunakan benar benar Camellia sinensis dan Mentha piperita.

Proses ekstraksi dilakukan dengan metode maserasi. Dalam penelitian ini digunakan daun teh hijau sebanyak $1276 \mathrm{~g}$ dan daun peppermint sebanyak $92 \mathrm{~g}$. Banyaknya daun teh hijau dan daun peppermint yang digunakan disesuaikan dengan penghitungan kebutuhan ekstrak cair yang diperlukan dalam pembuatan mouthwash (kebutuhan ekstrak teh hijau sebanyak $200 \mathrm{~mL}$ dan ekstrak peppermint sebanyak $45 \mathrm{~mL}$ ). Daun teh hijau dan peppermint yang telah dicuci dengan air bersih masing masing diblender kemudian diberikan pelarut etanol 96\% dengan perbandingan 1:5 dan didiamkan selama 3 hari. Hasil maserasi disaring dan diuapkan dengan menggunakan rotary evaporator untuk memperoleh ekstrak teh hijau dan esktrak peppermint cair.

Formula sediaan mouthwash dibuat dengan mencampurkan ekstrak teh hijau dan peppermint dengan bahan pelengkap sesuai dengan teknik pencampuran rasio. Formula mouthwash dapat dilihat pada Tabel 1.

Tabel 1. Formulasi Mouthwash

\begin{tabular}{|c|c|c|c|c|c|c|c|c|c|c|c|}
\hline \multirow{2}{*}{ Bahan } & \multirow{2}{*}{ Kegunaan } & \multirow{2}{*}{$\begin{array}{c}\text { Satuan } \\
\text { konsentrasi }\end{array}$} & \multicolumn{9}{|c|}{ Komposisi (\%) } \\
\hline & & & F1 & F2 & F3 & F4 & F5 & FA & FB & $\mathbf{K}(+)$ & K (-) \\
\hline $\mathrm{NaCl}$ & $\begin{array}{l}\text { Pengawet } \\
\text { osmolitik }\end{array}$ & $\mathrm{b} / \mathrm{v}$ & 1 & 1 & 1 & 1 & 1 & 1 & 1 & - & - \\
\hline Asam benzoat & Pengawet & $\mathrm{b} / \mathrm{v}$ & 0,5 & 0,5 & 0,5 & 0,5 & 0,5 & 0,5 & 0,5 & - & - \\
\hline Sorbitol & $\begin{array}{l}\text { Perisa dan } \\
\text { humektan }\end{array}$ & $\mathrm{b} / \mathrm{v}$ & 5 & 5 & 5 & 5 & 5 & 5 & 5 & - & - \\
\hline $\begin{array}{l}\text { Peppermint } \\
\text { oil }\end{array}$ & Perisa & $\mathrm{v} / \mathrm{v}$ & 1 & 1 & 1 & 1 & 1 & 1 & 1 & - & - \\
\hline $\begin{array}{l}\text { Campuran } \\
\text { ekstrak teh } \\
\text { hijau dan } \\
\text { peppermint }\end{array}$ & Bahan aktif & $\mathrm{v} / \mathrm{v}$ & 20 & 40 & 60 & 80 & 100 & - & - & - & - \\
\hline $\begin{array}{l}\text { Ekstrak teh } \\
\text { hijau }\end{array}$ & Bahan aktif & $\mathrm{v} / \mathrm{v}$ & - & - & - & - & - & 20 & - & - & - \\
\hline $\begin{array}{c}\text { Ekstrak } \\
\text { peppermint }\end{array}$ & Bahan aktif & $\mathrm{v} / \mathrm{v}$ & - & - & - & - & - & - & 20 & - & - \\
\hline Aquades ad & Pelarut & ad & 100 & 100 & 100 & 100 & - & 100 & 100 & 100 & 100 \\
\hline Amoxicillin & Kontrol positif & $\mathrm{b} / \mathrm{v}$ & - & - & - & - & - & - & - & 20 & - \\
\hline
\end{tabular}


Keterangan :

F1 : Campuran ekstrak teh hijau dan peppermint $20 \%$

F2 : Campuran ekstrak teh hijau dan peppermint $40 \%$

F3 : Campuran ekstrak teh hijau dan peppermint $60 \%$

F4 : Campuran ekstrak teh hijau dan peppermint $80 \%$

F5 : Campuran ekstrak teh hijau dan peppermint $100 \%$

FA : Ekstrak teh hijau 20\%

FB : Ekstrak peppermint $20 \%$

$\mathrm{K}(+) \quad$ : Amoxicillin

$\mathrm{K}(-) \quad$ : Akuades

Evaluasi sifat fisik mouthwash meliputi pengujian $\mathrm{pH}$ dan organoleptis dilaksanakan pada hari ke-0, 7, 14, 21, 28 dan 35. Uji pH dilakukan dengan menggunakan indikator universal. Uji organoleptis meliputi pengamatan warna, aroma dan rasa.

Skrining fitokimia dilakukan dengan menggunakan reagen spesifik untuk menguji ada tidaknya kandungan metabolit sekunder yang meliputi alkaloid, saponin, tanin, fenol, flavonoid, triterpenoid, steroid, dan antrakinon.

Media kultur bakteri Streptococcus mutans yang digunakan dalam penelitian ini adalah media agar TYC (Triptone, Yeast extract, Cystine). $250 \mathrm{~g}$ TYC agar base dilarutkan dalam $1000 \mathrm{~mL}$ akuades pada labu Erlenmeyer dan dipanaskan hingga larut. Agar disterilisasi menggunakan autoklaf pada suhu $12^{\circ} \mathrm{C}$ selama 15 menit dan didinginkan hingga suhu turun menjadi $50^{\circ} \mathrm{C}$. Agar dicampur hingga rata dan dituangkan ke dalam cawan petri.

Peremajaan bakteri dilakukan dengan cara menanam Streptococcus mutans murni pada media agar TYC dalam cawan petri. Selanjutnya dilakukan inkubasi pada suhu $37^{\circ} \mathrm{C}$ selama 48 jam. Kemurnian bakteri Streptococcus mutans dikonfirmasi melalui pengecatan gram (gambaran kokus berderet kecil) dan uji fermentasi gula.
Bakteri Streptococcus mutans murni ditanam di larutan suspensi $\mathrm{NaCl} 0,9 \%$ menggunakan jarum inokulasi atau ose steril. Larutan suspensi dikocok dan tingkat kekeruhan larutan disetarakan dengan standar 0,5 McFarland.

Uji aktivitas antibakteri dilakukan dengan metode difusi cakram. Setelah bakteri dibiakkan di cawan petri, disediakan sembilan kertas cakram kosong. Masing masing kertas cakram direndam ke dalam larutan mouthwash F1, F2, F3, F4, F5, FA, $\mathrm{FB}$, kontrol positif (amoxicillin) dan kontrol negatif (akuades). Setelah perendaman selesai, kertas cakram diletakkan pada cawan petri steril dan didiamkan selama 30 menit. Kertas cakram kemudian diletakkan di permukaan medium agar TYC yang telah berisi biakan bakteri dan dilanjutkan dengan inkubasi pada suhu $37^{\circ}$ selama 48 jam. Pengujian ini dilakukan dengan empat kali pengulangan (quadruplo). Zona hambat nantinya diukur menggunakan jangka sorong (dalam satuan $\mathrm{mm})$.

Data diameter zona hambat larutan mouthwash yang diuji terhadap Streptococcus mutans diolah menggunakan piranti lunak Microsoft excel 2010 dan SPSS. Analisis data dilakukan secara komparatif dengan One Way ANOVA.

\section{Hasil}

Evaluasi Sifat Fisik Mouthwash

\section{Uji pH}

Tabel 2. Hasil Uji pH

\begin{tabular}{ccccccc}
\hline Formula & Hari ke-0 & Hari ke-7 & Hari ke-14 & Hari ke-21 & Hari ke-28 & Hari ke-35 \\
\hline F1 & 5 & 5 & 5 & 5 & 5 & 5 \\
F2 & 5 & 5 & 5 & 5 & 5 & 5 \\
F3 & 5 & 5 & 5 & 5 & 5 & 5 \\
F4 & 5 & 5 & 5 & 5 & 5 & 5 \\
F5 & 5 & 5 & 5 & 5 & 5 & 5 \\
FA & 5 & 5 & 5 & 5 & 5 & 5 \\
FB & 5 & 5 & 5 & 5 & 5 & 5 \\
\hline
\end{tabular}


Tabel 3. Hasil Uji Organoleptis

\begin{tabular}{|c|c|c|c|c|}
\hline Hari & Formula & Warna & Aroma & Rasa \\
\hline \multirow[t]{7}{*}{0} & F1 & $\begin{array}{c}\text { Hijau kekuningan } \\
\text { keruh }\end{array}$ & Mint kuat & Manis, rasa mint khas peppermint \\
\hline & $\mathrm{F} 2$ & Hijau tua keruh & Mint kuat & Cukup manis, rasa mint khas peppermint \\
\hline & $\mathrm{F} 3$ & $\begin{array}{c}\text { Hijau kecoklatan } \\
\text { keruh }\end{array}$ & Mint kuat & Sedikit manis, rasa mint khas peppermint \\
\hline & $\mathrm{F} 4$ & $\begin{array}{c}\text { Hijau kecoklatan } \\
\text { keruh }\end{array}$ & Mint kuat & Sedikit manis, rasa mint khas peppermint \\
\hline & F5 & $\begin{array}{c}\text { Hijau kecoklatan } \\
\text { keruh }\end{array}$ & Mint kuat & Sedikit manis, rasa mint khas peppermint \\
\hline & FA & Hijau tua keruh & Teh kuat & Manis, rasa khas teh hijau \\
\hline & FB & Coklat keruh & Mint kuat & Manis, rasa mint khas peppermint \\
\hline \multirow[t]{7}{*}{7} & $\mathrm{~F} 1$ & Hijau muda keruh & Mint kuat & Manis, rasa mint khas peppermint \\
\hline & $\mathrm{F} 2$ & Hijau tua keruh & Mint kuat & Cukup manis, rasa mint khas peppermint \\
\hline & F3 & $\begin{array}{c}\text { Hijau kecoklatan } \\
\text { keruh }\end{array}$ & Mint kuat & Sedikit manis, rasa mint khas peppermint \\
\hline & F4 & $\begin{array}{c}\text { Hijau kecoklatan } \\
\text { keruh }\end{array}$ & Mint kuat & Sedikit manis, rasa mint khas peppermint \\
\hline & F5 & $\begin{array}{c}\text { Hijau kecoklatan } \\
\text { keruh }\end{array}$ & Mint kuat & Sedikit manis, rasa mint khas peppermint \\
\hline & FA & Hijau tua keruh & Teh kuat & Manis, rasa khas teh hijau \\
\hline & FB & Coklat keruh & Mint kuat & Manis, rasa mint khas peppermint \\
\hline \multirow[t]{7}{*}{14} & $\mathrm{~F} 1$ & Hijau muda keruh & Mint kuat & Manis, rasa mint khas peppermint \\
\hline & $\mathrm{F} 2$ & Hijau tua keruh & Mint kuat & Cukup manis, rasa mint khas peppermint \\
\hline & F3 & $\begin{array}{l}\text { Hijau kecoklatan } \\
\text { keruh }\end{array}$ & Mint kuat & Sedikit manis, rasa mint khas peppermint \\
\hline & F4 & $\begin{array}{c}\text { Hijau kecoklatan } \\
\text { keruh }\end{array}$ & Mint kuat & Sedikit manis, rasa mint khas peppermint \\
\hline & F5 & $\begin{array}{c}\text { Hijau kecoklatan } \\
\text { keruh }\end{array}$ & Mint kuat & Sedikit manis, rasa mint khas peppermint \\
\hline & FA & Hijau tua keruh & Teh kuat & Manis, rasa khas teh hijau \\
\hline & FB & Coklat keruh & Mint kuat & Manis, rasa mint khas peppermint \\
\hline \multirow[t]{7}{*}{21} & $\mathrm{~F} 1$ & Hijau muda keruh & Mint lemah & Manis, rasa mint khas peppermint \\
\hline & $\mathrm{F} 2$ & Hijau tua keruh & Mint lemah & Cukup manis, rasa mint khas peppermint \\
\hline & $\mathrm{F} 3$ & $\begin{array}{c}\text { Hijau kecoklatan } \\
\text { keruh }\end{array}$ & Mint lemah & Sedikit manis, rasa mint khas peppermint \\
\hline & F4 & $\begin{array}{c}\text { Hijau kecoklatan } \\
\text { keruh }\end{array}$ & Mint lemah & Sedikit manis, rasa mint khas peppermint \\
\hline & F5 & $\begin{array}{c}\text { Hijau kecoklatan } \\
\text { keruh }\end{array}$ & Mint lemah & Sedikit manis, rasa mint khas peppermint \\
\hline & FA & Hijau tua keruh & Teh kuat & Manis, rasa khas teh hijau \\
\hline & FB & Coklat keruh & Mint kuat & Manis, rasa mint khas peppermint \\
\hline \multirow[t]{6}{*}{28} & $\mathrm{~F} 1$ & Hijau muda keruh & Mint lemah & Manis, rasa mint khas peppermint \\
\hline & $\mathrm{F} 2$ & Hijau tua keruh & Mint lemah & Cukup manis, rasa mint khas peppermint \\
\hline & F3 & $\begin{array}{c}\text { Hijau kecoklatan } \\
\text { keruh }\end{array}$ & Mint lemah & Sedikit manis, rasa mint khas peppermint \\
\hline & $\mathrm{F} 4$ & $\begin{array}{c}\text { Hijau kecoklatan } \\
\text { keruh }\end{array}$ & Mint lemah & Sedikit manis, rasa mint khas peppermint \\
\hline & F5 & $\begin{array}{c}\text { Hijau kecoklatan } \\
\text { keruh }\end{array}$ & Mint lemah & Sedikit manis, rasa mint khas peppermint \\
\hline & FA & Hijau tua keruh & Teh kuat & Manis, rasa khas teh hijau \\
\hline
\end{tabular}




\section{Coklat keruh}

Hijau muda keruh Hijau tua keruh Hijau kecoklatan keruh

F4

F5

FA

FB keruh keruh

Hijau tua keruh Coklat keruh
Mint kuat

Mint lemah

Mint lemah

Mint lemah

Mint lemah

Mint lemah

Teh kuat Mint kuat
Manis, rasa mint khas peppermint

Manis, rasa mint khas peppermint

Cukup manis, rasa mint khas peppermint

Sedikit manis, rasa mint khas peppermint

Sedikit manis, rasa mint khas peppermint

Sedikit manis, rasa mint khas peppermint

Manis, rasa khas teh hijau Manis, rasa mint khas peppermint

\section{Skrining Fitokimia}

Tabel 4. Hasil Skrining Fitokimia Mouthwash Kombinasi Ekstrak Camellia sinensis (Teh Hijau) dan Mentha piperita (Peppermint)

\begin{tabular}{cccc}
\hline Kandungan kimia & Pereaksi & Hasil pengamatan & Kesimpulan \\
& & & \\
\hline Alkaloid & Dragendorff & Larutan jingga, tidak ada endapan & - \\
& Meyer & Larutan jingga, tidak ada endapan & - \\
& Wagner & Larutan jingga, tidak ada endapan & - \\
Saponin & $\mathrm{AKuades} \mathrm{panas}_{\text {Timbul busa stabil selama }>10 \text { menit }}$ & + \\
Tanin & $\mathrm{FeCl}_{3} 3 \%$ & Larutan hitam & + \\
& $\mathrm{Gelatin}$ & Terdapat endapan & + \\
Fenol & $\mathrm{FeCl}_{3} 3 \%$ & Larutan hitam & + \\
Triterpenoid & $\mathrm{Mg} \mathrm{dan} \mathrm{HCL} \mathrm{pekat}$ & Larutan merah jingga & + \\
Steroid & Asam asetat anhidrat dan & Larutan merah & - \\
Antrakinon & $\mathrm{H}_{2} \mathrm{SO}_{4}$ pekat & Larutan merah & + \\
\hline
\end{tabular}

\section{Uji Aktivitas Antibakteri}

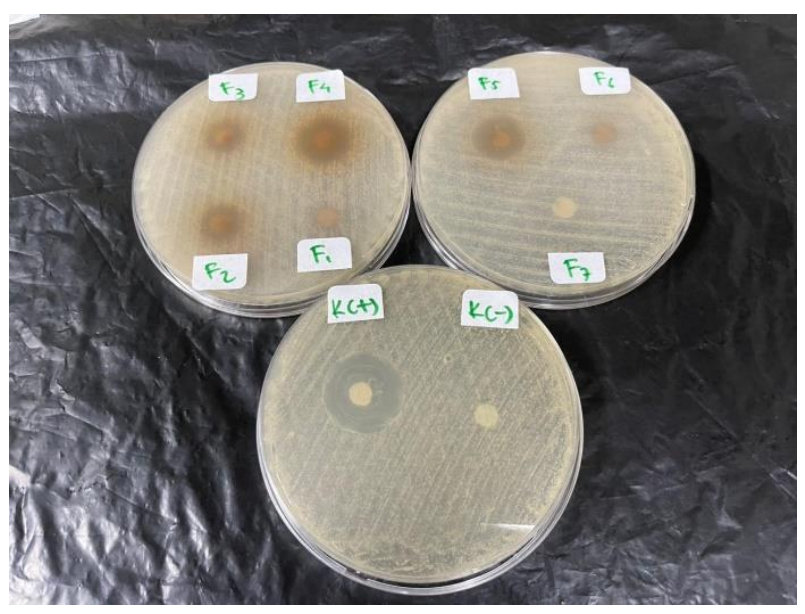

Gambar 1. Hasil Difusi Cakram Mouthwash Berbahan Dasar Kombinasi Ekstrak Camellia sinensis dan Mentha piperita 
Tabel 5. Hasil Uji Aktivitas Antibakteri Mouthwash Berbahan Dasar Kombinasi Ekstrak Camellia sinensis dan Mentha piperita terhadap Bakteri Streptococcus mutans

\begin{tabular}{|c|c|c|c|c|c|c|c|}
\hline \multirow[t]{2}{*}{ Kode } & \multicolumn{4}{|c|}{ Diameter zona hambat (mm) } & \multirow{2}{*}{$\begin{array}{c}\text { Rata rata } \\
(\mathbf{m m})\end{array}$} & \multirow{2}{*}{$\begin{array}{c}\text { Daya } \\
\text { hambat }\end{array}$} & \multirow[b]{2}{*}{ Kategori Daya Hambat } \\
\hline & $\mathbf{I}$ & II & III & IV & & & \\
\hline F1 & 8,20 & 8,15 & 8,40 & 8,60 & 8,34 & Sedang & Kategori daya hambat \\
\hline $\mathrm{F} 2$ & 9,40 & 9,80 & 9,95 & 10,05 & 9,80 & Sedang & menurut $\mathrm{Su}$ \\
\hline F3 & 11,40 & 11,80 & 11,60 & 11,75 & 11,64 & Kuat & (2016) : \\
\hline F4 & 14,20 & 14,60 & 14,75 & 14,95 & 14,63 & Kuat & \\
\hline F5 & 15,05 & 15,80 & 16,20 & 16,60 & 15,91 & Kuat & (1) Lemah: $\leq 5 \mathrm{~mm}$; \\
\hline FA & 7,40 & 8,05 & 7,20 & 7,15 & 7,45 & Sedang & $(2$ \\
\hline FB & 6,20 & 6,15 & 6,05 & 6,40 & 6,20 & Sedang & (3) $11-20 \mathrm{~mm}$ : Kuat; \\
\hline $\mathrm{K}(+)$ & 18,05 & 18,00 & 18,20 & 18,35 & 18,15 & Kuat & \\
\hline $\mathrm{K}(-)$ & 0,00 & 0,00 & 0,00 & 0,00 & 0,00 & - & \\
\hline
\end{tabular}

\section{Pembahasan}

Analisis yang dilakukan dalam penelitian ini meliputi evaluasi sifat fisik mouthwash (pengujian $\mathrm{pH}$ dan organoleptis), skrining fitokimia dan aktivitas antibakteri.

Uji pH larutan mouthwash berbahan dasar ekstrak Camellia sinensis dan Mentha piperita dilakukan selama 35 hari pada suhu kamar. Tabel 2 menunjukkan bahwa F1 sampai F5 memiliki nilai $\mathrm{pH}$ 5. Hasil uji $\mathrm{pH}$ tidak menunjukkan adanya perubahan nilai $\mathrm{pH}$ selama penyimpanan. Seluruh formulasi mouthwash dalam penelitian ini memenuhi nilai $\mathrm{pH}$ standar sediaan mouthwash herbal yakni harus berada pada rentang 5-7. ${ }^{25}$

Uji organoleptis yang juga dilakukan selama 35 hari pada suhu kamar menunjukkan bahwa tidak terjadi perubahan signifikan baik pada warna, aroma dan rasa mouthwash (Tabel 3). Selain itu, tidak didapatkan adanya perubahan warna, aroma dan rasa yang mengarah pada tanda tanda kontaminasi mikroorganisme lain seperti munculnya bercak putih (tanda pertumbuhan jamur) dan aroma yang cenderung berbau tidak sedap. Melalui pengujian organoleptis disimpulkan bahwa larutan mouthwash yang diuji memiliki tingkat kestabilan yang baik.

Berdasarkan hasil skrining fitokimia (Tabel 4) dapat disimpulkan bahwa metabolit sekunder yang terkandung di dalam mouthwash berbahan dasar kombinasi ekstrak teh hijau dan peppermint adalah saponin, tanin, fenol, flavonoid, triterpenoid dan antrakinon. Senyawa kimia tersebut berpengaruh terhadap adanya aktivitas antibakteri mouthwash yang diteliti terhadap Streptococcus mutans.

Masing masing senyawa kimia memiliki mekanisme antibakteri tersendiri. Saponin bekerja dengan mengganggu permeabilitas membran sel dan pertumbuhan bakteri. Fenol menyebabkan hiperpolarisasi membran sel dan mengganggu pembelahan DNA. Flavonoid bersifat lipofilik dan merusak membran sel. Tanin dapat merusak protoplasma. Triterpenoid merusak porin (protein transmembran pada membran luar dinding sel bakteri). Antrakinon menyebabkan destabilisasi dinding sel dan dapat mengganggu metabolisme bakteri melalui stres oksidatif. ${ }^{26-30}$ Seluruh senyawa kimia tersebut bekerja secara sinergis untuk memunculkan aktivitas antibakteri terhadap Streptococcus mutans.

Uji aktivitas antibakteri larutan mouthwash dilakukan dengan menggunakan metode difusi cakram. Aktivitas antibakteri ditentukan melalui ukuran zona hambat yang terbentuk pada media agar TYC. Dari hasil pengukuran zona hambat tiap formula pada Tabel 5 didapatkan bahwa semakin tinggi konsentrasi ekstrak teh hijau dan peppermint maka semakin besar pula diameter zona hambat yang terbentuk. Rata rata zona hambat F1 (campuran ekstrak teh hijau dan peppermint 20\%) sebesar 8,34 mm dan F2 (campuran ekstrak teh hijau dan peppermint $40 \%$ ) sebesar $9,80 \mathrm{~mm}$. Baik F1 dan F2 tergolong memiliki daya hambat sedang. Sementara itu, rata rata zona hambat F3 (campuran ekstrak teh hijau dan peppermint 60\%) sebesar 11,64 mm, F4 (campuran ekstrak teh hijau dan peppermint $80 \%$ ) sebesar $14,63 \mathrm{~mm}$ dan $\mathrm{F} 5$ (campuran ekstrak teh hijau dan peppermint 100\%) sebesar 15,91 mm. F3, F4 dan F5 tergolong memiliki daya hambat kuat. F5 memiliki zona hambat terbesar akan tetapi ukuran zona hambat yang terbentuk masih berada di bawah kontrol positif (amoxicillin).

Mekanisme kerja amoxicillin jauh lebih spesifik dibandingkan dengan mekanisme kerja metabolit sekunder yang terkandung dalam kombinasi ekstrak teh hijau dan peppermint. Amoxicillin merupakan golongan beta laktamase 
yang memiliki kemampuan untuk mengikat penicillin-binding protein pada bakteri sehingga terjadi penghambatan proses transpeptidasi yang berdampak pada aktivasi enzim autolitik pada dinding sel bakteri. Proses tersebut mengakibatkan adanya lisis dinding sel bakteri secara masif yang menyebabkan kematian bakteri. Mekanisme spesifik semacam ini pada akhirnya berdampak pada ukuran zona hambat amoxicillin yang lebih besar dibandingkan zona hambat larutan mouthwash yang diuji. ${ }^{31}$

Meskipun F5 memiliki zona hambat yang masih berada di bawah kontrol positif (amoxicillin), ukuran zona hambat F5 terbukti lebih besar dibandingkan dengan ukuran zona hambat yang dihasilkan oleh obat kumur di pasaran. Berdasarkan penelitian sebelumnya, ukuran zona hambat Listerine Green Tea, Betadine obat kumur dan Minosep terhadap Streptococcus mutans masing masing sebesar $14,2 \mathrm{~mm}, 8,3 \mathrm{~mm}$ dan $15,7 \mathrm{~mm} \cdot{ }^{32,33}$ Hal ini menunjukkan bahwa F5 memiliki aktivitas penghambatan terhadap Streptococcus mutans yang lebih besar dibandingkan dengan obat kumur yang tersedia di pasaran.

Tabel 6. Analisis One Way ANOVA antara Peningkatan Konsentrasi Ekstrak terhadap Ukuran Zona Hambat

\begin{tabular}{ccccc}
\hline Kode & N & Rata rata & Standar Deviasi & Nilai p \\
\hline F1 & 4 & 8,34 & 0,21 & \\
F2 & 4 & 9,80 & 0,29 & \\
F3 & 4 & 11,64 & 0,18 & $0,000^{*}$ \\
F4 & 4 & 14,63 & 0,32 & \\
F5 & 4 & 15,91 & 0,66 & \\
Kontrol (+) & 4 & 18,15 & 0,16 & \\
Kontrol (-) & 4 & 0,00 & 0,00 & \\
\hline
\end{tabular}

Keterangan :

${ }^{*}=$ Ada perbedaan bermakna

Berdasarkan hasil analisis statistik One Way ANOVA antara peningkatan konsentrasi ekstrak terhadap ukuran zona hambat pertumbuhan Streptococcus mutans, diperoleh $p$ value 0,000 $(\mathrm{p}<0,05)$. Hal tersebut menunjukkan bahwa peningkatan konsentrasi ekstrak teh hijau dan peppermint menimbulkan adanya perbedaaan bermakna pada ukuran zona hambat pertumbuhan Streptococcus mutans.

Tabel 7. Analisis One Way ANOVA antara Ada Tidaknya Kombinasi Tanaman terhadap Ukuran Zona Hambat

\begin{tabular}{ccccc}
\hline Kode & N & Rata rata & Standar Deviasi & Nilai p \\
\hline F1 & 4 & 8,34 & 0,21 & \\
FA & 4 & 7,45 & 0,41 & $0,000^{*}$ \\
FB & 4 & 6,20 & 0,15 & \\
Kontrol (+) & 4 & 18,15 & 0,16 & \\
Kontrol (-) & 4 & 0,00 & 0,00 & \\
\hline
\end{tabular}

Keterangan :

${ }^{*}=$ Ada perbedaan bermakna

Selain dipengaruhi oleh besarnya konsentrasi ekstrak teh hijau dan peppermint, ukuran zona hambat juga dipengaruhi oleh ada tidaknya kombinasi tanaman. Hal ini dapat dilihat dengan membandingkan ukuran zona hambat F1, FA dan FB pada Tabel 4. Ukuran zona hambat terbesar berada pada $F 1$ dengan rata rata zona hambat sebesar 8,34 mm sedangkan pada FA (ekstrak teh hijau 20\%) sebesar 7,45 mm dan FB (ekstrak peppermint 20\%) sebesar 6,20 $\mathrm{mm}$. Dengan demikian dapat disimpulkan bahwa mouthwash berbahan dasar percampuran dua ekstrak tanaman menghasilkan zona hambat yang lebih besar dibanding mouthwash dengan satu ekstrak tanaman. Hal tersebut dikonfirmasi pula dengan hasil analisis statistik One Way ANOVA antara ada 
tidaknya kombinasi tanaman terhadap ukuran zona hambat yang menghasilkan $p$ value $0,000(\mathrm{p}<0,05)$ yang berarti kombinasi tanaman memberikan perbedaan bermakna terhadap zona hambat pertumbuhan Streptococcus mutans.

\section{Simpulan}

Berdasarkan hasil penelitian dapat disimpulkan bahwa mouthwash berbahan dasar kombinasi ekstrak Camellia sinensis dan Mentha piperita dengan konsentrasi $100 \%$ adalah yang paling efektif sebagai antibakteri terhadap Streptococcus mutans. Diperlukan penelitian lebih lanjut berupa studi in vivo untuk mengetahui gambaran efektivitas mouthwash secara nyata pada orang coba.

\section{Ucapan Terima Kasih}

Ucapan terimakasih ditujukan $\begin{array}{r}\text { kepada } \\ \text { telah }\end{array}$
KEMENDIKBUD-RISTEK yang
memberikan pendanaan penelitian serta dosen
pengampu Program Kreativitas Mahasiswa (PKM)
Universitas Airlangga, Laboratorium Materia
Medica Batu, Laboratorium Poltekkes Malang dan
Research Center Fakultas Kedokteran Gigi
Universitas Airlangga yang turut membantu dalam
kelancaran penelitian ini.

\section{Daftar Pustaka}

1. Infodatin. Kesehatan gigi nasional 2019. Dikutip pada tanggal 10 Oktober 2021. Diunduh dari https://pusdatin.kemkes.go.id/resources/downl oad/pusdatin/infodatin/infodatin-gigi.pdf.

2. Riskesdas. Laporan nasional riskesdas 2018 . Dikutip pada tanggal 25 September 2021. Diunduh dari http://labdata.litbang.kemkes.go.id/images/do wnload/laporan/RKD/2018/Laporan_Nasional _RKD2018_FINAL.pdf.

3. Mitchell L, David AM, Caul L. Kedokteran gigi klinik. Jakarta: ECG; 2014.

4. Ramayanti S, Purnakarya I. Peran makanan terhadap kejadian karies gigi. Jurnal Kesehatan Masyarakat Andalas. 2013;7(2):89-93.

5. Soeyoso UM, Muntaha A, Malaka T, Zaman C. Prevalensi dan faktor risiko karies gigi murid Sekolah Dasar Kelas III-IV Negeri 161 Kota Palembang tahun 2009. Jurnal Kesehatan Bina Husada. 2010;6(1):12-20.

6. BaniHani A, Deery C, Toumba J, Munyombwe
T, Duggal M. The impact of dental caries and its treatment by conventional or biological approaches on the oral health-related quality of life of children and carers. International Journal of Paediatric Dentistry. 2018;28(2):266-76.

7. Mervrayano J, Rahmatini R, Bahar E. Perbandingan efektivitas obat kumur yang mengandung chlorhexidine dengan povidone iodine terhadap Streptococcus. Jurnal Kesehatan Andalas. 2015;4(1):168-71.

8. Rieger M. Harry's Cosmetology $7^{\text {th }}$ edition. London: Chemical Publishing; 2001.

9. Bahna P, Hanna HA, Dvorak T, Vaporciyan A, Chambers M, Raad I. Antiseptic effect of a novel alcohol-free mouthwash: a convenient prophylactic alternative for high-risk patients. Oral Oncology. 2007;43(2):159-64.

10. Amelia R, Sudomo P, Widasari L. Perbandingan uji efektivitas ekstrak teh hijau (Camellia sinensis) sebagai antibakteri terhadap bakteri Staphylococcus aureus dan Escherichia coli secara in vitro. Bina Widya. 2012;4:177-82.

11. Annita A, Panus H. Daya hambat ekstrak daun teh hijau (Camellia sinensis) terhadap bakteri Streptococcus mutans. Jurnal Kesehatan Saintika Meditory. 2018;1(1):1-9.

12. Martono B, Setiyono RT. Skrining fitokimia enam genotipe teh. Jurnal Tanaman Industri dan Penyegar. 2014;1(2):63-8.

13. Trevisan SC, Menezes AP, Barbalho SM, Guiguer ÉL. Properties of Mentha piperita: a brief review. World J Pharm Med Res. 2017;3(1):309-13.

14. Golestannejad Z, Gavanji S, Mohammadi E, Motamedi A, Bahrani M, Rezaei $\mathrm{F}$, et al. Comparison of antibacterial activity of essential oils of Foeniculum vulgare Mill, Mentha arvensis and Mentha piperita against Streptococcus mutans. Advanced Herbal Medicine. 2017;3(1):3-13.

15. Patil SR, Patil RS, Godghate AG. Mentha piperita Linn: Phytochemical, antibacterial and dipterian adulticidal approach. Int J Pharm Pharm Sci. 2016;8(3):352-5.

16. Setiawan A, Kunarto B, Sani EY. Ekstraksi daun peppermint (Mentha piperita L.) menggunakan metode microwave assisted extraction terhadap total fenolik, tanin, flavonoid dan aktivitas antioksidan. J Petrol. 2013;369(1):1689-99.

17. Badan Pusat Statistik. Produksi Tanaman Perkebunan (Ribu Ton) 2018-2020. Dikutip pada tanggal 6 Desember 2021. Diunduh dari 
https://www.bps.go.id/indicator/54/132/1/pro duksi-tanaman-perkebunan.html.

18. Panche AN, Diwan AD, Chandra SR. Flavonoids: an overview. Journal of Nutritional Science. 2016;5(47):1-15.

19. Laoli KFT. Pengaruh penambahan ekstrak daun peppermint (Mentha piperita) terhadap tingkat kesukaan aroma dan rasa serta aktivitas antioksidan permen jelly buah mengkudu (Morinda citrifolia). Skripsi. Yogyakarta: Universitas Sanata Dharma; 2019.

20. Otieno JN, Hosea KM, Lyaruu HV, Mahunnah RL. Multi-plant or single-plant extracts, which is the most effective for local healing in Tanzania?. African Journal of Traditional, Complementary and Alternative Medicines. 2008;5(2):165-72.

21. BPOM. Serial data ilmiah terkini tumbuhan obat. Jakarta: BPOM; 2016.

22. Backer CA, Bakhuizen Van Den Brink RC. Flora of Java (spermatophytes only), vol I. Groningen: NVP Noordhoff; 1963.

23. Backer CA, Bakhuizen Van Den Brink RC. Flora of Java (spermatophytes only), vol II. Groningen: NVP Noordhoff; 1965.

24. Van Steenis CGGJ. Flora: untuk sekolah di Indonesia. Jakarta: Pradnya Paramita; 2008.

25. Hidayanto A, Manikam AS, Pertiwi WS, Harismah K. Formulasi obat kumur ekstrak daun kemangi (Ocimum Basilicum L) dengan pemanis alami Stevia (Stevia Rebaudiana Bertoni). URECOL. 2017;8:189-94.

26. Arabski M, Węgierek-Ciuk A, Czerwonka G, Lankoff A, Kaca W. Effects of saponins against clinical E. coli strains and eukaryotic cell line. Journal of Biomedicine and Biotechnology. 2012;2012:1-6.

27. Juliantina F, Citra DA, Nirwani B, Nurmasitoh
T, Bowo ET. Manfaat sirih merah (Piper crocatum) sebagai agen anti bakterial terhadap bakteri gram positif dan bakteri gram negatif. Jurnal Kedokteran dan Kesehatan Indonesia. 2009;1:12-20.

28. Malmir M, Serrano R, Silva O, Mendez-Vilas A. Antimicrobial research: Novel bioknowledge and educational programs. Formatex. 2017;1:55-61.

29. Sakinah N, Dwyana Z, Tambaru E, Rante H. Uji aktivitas sediaan obat kumur ekstrak daun Miana Coleus Scutellarioides (L.) Benth terhadap pertumbuhan bakteri Streptococcus mutans. Core. 2016;1:1-7.

30. Wu Y, Bai J, Zhong K, Huang Y, Qi H, Jiang $\mathrm{Y}$, et al. Antibacterial activity and membranedisruptive mechanism of 3-p-trans-coumaroyl2-hydroxyquinic acid, a novel phenolic compound from pine needles of Cedrus deodara, against Staphylococcus aureus. Molecules. 2016;1084:1-12.

31. Bernatová S, Samek O, Pilát Z, Šerý M, Ježek J, Jákl P, et al. Following the mechanisms of bacteriostatic versus bactericidal action using Raman spectroscopy. Molecules. 2013;18(11):13188-99.

32. Mierza V, Sudewi S. Uji aktivitas antibakteri sediaan obat kumur ekstrak etanol buah kapulaga (Amomum Compactum Sol. Ex Maton) terhadap pertumbuhan bakteri Staphylococcus Aureus dan Streptococcus Mutans. Journal of Pharmaceutical and Sciences. 2020;3(1):50-7.

33. Sinuraya YA. Formulasi dan uji aktivitas antibakteri sediaan obat kumur ekstrak etanol daun ketapang (Terminalia catappa L.) Skripsi. Medan: Universitas Sumatera Utara; 2021. 